Nuntius Antiquus, Belo Horizonte, v. 12, n. 2, p. 133-157, 2016

\title{
Et me remorsurum petis? \\ Uma promessa de invectiva nos Epodos de Horácio ${ }^{1}$
}

\author{
Et me remorsurum petis? \\ A promise of invective in Horace's Epodes
}

Guilherme Gontijo Flores

Universidade Federal do Paraná

Curitiba, Paraná / Brasil

ggontijof@gmail.com

Resumo: É de grande conhecimento - e tema de rara concordância - entre os classicistas que o poeta romano Quinto Horácio Flaco é um grande ironista. Sua poesia está repleta de duplos sentidos, autoderrisão e logros; mas alguém poderia perguntar o que acontece (ou o que se performa) quando encaramos o gume da ironia em termos de política. Nesse caso, o livro de Epodos, publicado pouco tempo depois da Batalha do Ácio (31 a.C.), pode servir como um exemplo perfeito de como um livro poético seria capaz de apresentar um projeto político complexo por meio das ambages da ironia. Para realizar essa leitura, analisarei aqui os sete primeiros epodos, com ênfase no último deles.

Palavras-chave: invectiva; Horácio; Epodos; poesia romana; tradução.

Abstract: It is well known among classicists - and a matter of rare agreement - that the Roman poet Quintus Horatius Flaccus (Horace) is a great ironist. His poetry is full of double meanings, self mockery and deceptions; but one could ask what happens (or what is performed) when we are facing irony's edge in political terms. In such a case, the book of Epodes, published a few years after the Battle of Actium (31 BC), may well serve as perfect example of how

\footnotetext{
${ }^{1}$ Gostaria de agradecer a leitura e os comentários de Bernardo Brandão, Rodrigo Tadeu Gonçalves e Sergio Maciel.
} 
a poetic book could be able to present a complex political project through the meanders of irony. In order to accomplish that reading, I will analyze here the first 7 epodes with emphasis on the last one.

Keywords: invective; Horace; Epodes; Roman poetry; translation.

Recebido em 10 de outubro de 2016.

Aprovado em 1 de dezembro de 2016.

Num ensaio bastante conhecido, David Foster Wallace, ao pensar sobre os problemas da ironia contemporânea e suas implicações políticas, resumiu assim a questão:

E não resta dúvida: a ironia nos tiraniza. Nossa difusa ironia cultural é, ao mesmo tempo, tão poderosa e tão frustrante porque é impossível saber com clareza o que quer um ironista. Toda a ironia americana se baseia num argumento implícito: "Na verdade, eu não quero dizer o que estou dizendo". Mas então o que a ironia como norma cultural quer dizer? Que é impossível querer dizer o que se diz? Que talvez seja mesmo uma pena ser impossível, mas acorde para a vida e pare de sonhar? Acredito que, no fim das contas, a ironia de hoje está provavelmente dizendo o seguinte: "Que coisa absolutamente banal você me perguntar o que eu quero dizer". Qualquer um que tenha a petulância herética de perguntar a um ironista o que ele na verdade defende acaba por parecer histérico ou careta. Eis o caráter opressivo da ironia institucionalizada, do rebelde bem-sucedido demais: a capacidade de interditar a questão sem se reportar a seu conteúdo é, quando exercida, tirania. ${ }^{2}$ (WALLACE, 2009, p. 187)

\footnotetext{
${ }^{2} \mathrm{O}$ ensaio em questão chama-se "E unibus pluram: Television and U.S. fiction", do livro A supposedly fun thing I'll never do again, de 1997. Porém, cito os trechos que
} 
A preocupação de Wallace é fundamental para nos perguntarmos sobre alguns aspectos das posturas políticas assumidas pelos intelectuais ocidentais nas últimas décadas. A recusa de uma afirmatividade direta, ou a recusa de um "querer dizer", aponta para um abismo que pode ser tirânico. Ao sair de uma posição política clara, o ironista se defende do risco de cair pelas suas ideias. No entanto, como podemos depreender da própria passagem de Wallace, não é a ironia per se que constitui um problema contemporâneo, mas sua apresentação tirânica, sua transformação em regra de conduta cotidiana, artística, política. "É crítica e destrutiva, boa para limpar o terreno. Com certeza era assim que nossos pais pós-modernos a viam. Mas particularmente inútil quando se trata de construir alguma coisa para pôr no lugar das hipocrisias que expõe" (WALLACE, 2009, p. 186). Seria então possível pensar num modelo de ironia que se revela politicamente mais forte? E mais, seria possível encontrarmos exemplos no passado de uma ironia que contenha em si o germe da proposição? É o que busco analisar numa sequência poética de Quinto Horácio Flaco, publicada em torno de 30 a.C. Nesse sentido, pensar sobre estratégias políticas da ironia (seria difícil afirmar uma política da ironia) poderia abrir um espaço para novas questões irônicas do presente, que não tendessem a cair no modelo tirânico. Mas certamente não evitariam o risco, já que uma recursividade irônica contamina todo discurso daquele que é identificado como ironista. Em outras palavras, depois que convivemos com um texto irônico e que o supomos como tal, como estabelecer o limite da interpretação irônica?

Os Epodos, ou Iambos, de Horácio, permanecem sendo a obra menos estudada de seu corpus, apesar de termos alguns trabalhos importantes nas últimas décadas, tais como o de Carrubba (1969), Watson (2003) e Johnson (2012), dentre outros. No Brasil, temos há pouco tempo o importante estudo de Alexandre Hasegawa (2010), que além de fazer um estudo da organização do livro, apresenta uma tradução poética integral dos poemas. Diante dessas figuras, pretendo aqui fazer uma pequena contribuição sobre possibilidades políticas da poética epódica, ou, em outras palavras, quero pensar como a tradição arquiloquiana é remodelada por Horácio até termos a possibilidade de uma voz nova, preocupada com a política romana após as guerras civis. Para tanto,

foram traduzidos para o português, no número 6 da revista Serrote, onde infelizmente não consta o nome do tradutor. 
busco compreender a leitura programática do epodo 6; porém, antes de analisar a peça, comentarei apenas o movimento inicial do livro, os cinco primeiros poemas até a aparição de Canídia, no epodo 5, a fim de percebermos como a voz - ou melhor, a multiplicidade de vozes - se apresenta até este ponto programático. Uma parte do argumento se embasa na monometria desses poemas - todos escritos em trímetro iâmbico seguido por dímetro iâmbico - e no fato de que a escrita antiga de poesia, no tempo de Horácio (sem separação entre palavras, versos, ou mesmo poemas), por vezes poderia confundir o leitor sobre o começo e o fim de cada peça; essa ambiguidade métrica e temática será fundamental para pensarmos a confusão como modelo de poética e política e o iambo horaciano como modelo de autodefesa e defesa do alheio.

O primeiro epodo parece um anúncio da batalha naval do Ácio, em 31 a.C., embora os dados permaneçam bastante vagos no poema e seja possível (ainda que pouco provável) sugerir que se trate dos acontecimentos de 38-36 a.C., nas campanhas contra Sexto Pompeu. Sabemos que em 32 a.C. Otaviano (o futuro Augusto) rompeu oficialmente sua aliança com Marco Antônio e declarou guerra ao Egito, para velar o conflito civil. Poderíamos então nos perguntar se Mecenas foi, de fato, à batalha, já que tudo indica que ele ocupou os afazeres políticos de Augusto em Roma, no período da campanha bélica. De qualquer modo, temos aqui uma espécie de propemptikón (poema de boa viagem), seguido do desejo que o poeta explicita: viajar junto com seu patrono, correr o mesmo risco num modelo especular. Outra questão fundamental para a abertura do livro é a relação de amizade que marcará boa parte dos jogos entre ataques e louvores, que se desenvolverão nos próximos poemas; amicitia é então um vínculo de valores e preza pelo desinteresse, tal como vemos também em Cícero (Da amizade 26-32, 42 et seq.); mas que aqui se desenvolve num paralelismo entre a amizade de Horácio por Mecenas e a deste por Otaviano: se Mecenas segue Otaviano por amizade, também por amizade Horácio seguiria Mecenas à guerra, ou pelo menos isso é o que nos é prometido. O que é notável para um poema iâmbico na abertura do livro é que o riso aparece de modo sutil, talvez sutil demais, para a expectativa do gênero. Talvez essa grande ênfase à amizade, num ponto estratégico do livro, nos remeta a Arquíloco, frag. 15 West:

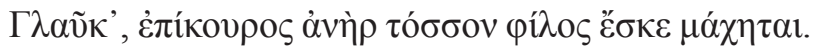


Glauco, um mercenário é amigo enquanto combate.

No entanto, em contraponto à seriedade que inicia a peça, vemos uma comparação do próprio poeta com uma galinha aflita com seus filhotes

ut adsidens implumibus pullis auis

serpentium allapsus timet

magis relictis, non, ut adsit, auxili

latura plus praesentibus. ${ }^{3}$

igual galinha quando à prole implume assim

atenta e teme a víbora

por quem desgarra, mesmo se ela é incapaz

de tolerar ataques tais. ${ }^{4}$

(v. 19-22)

E, em seguida, temos a crítica às ambições econômicas que movem as guerras, uma lembrança talvez incomodamente desnecessária num poema sobre amizade.

\author{
Libenter hoc et omne militabitur \\ bellum in tuae spem gratiae, \\ non ut iunencis illigata pluribus \\ aratra nitantur mea \\ pecusue Calabris ante sidus feruidum \\ Lucana mutet pascuis, \\ neque ut superni uilla candens Tusculi \\ Circaea tangat moenia.
}

\footnotetext{
${ }^{3}$ Em todas as citações dos Epodos sigo a edição teubneriana de Shackleton Bailey (2001). ${ }^{4}$ Todas as traduções são de minha autoria: elas se pretendem poéticas, não literais, e têm o intuito de emular o metro antigo para performance vocal [cf. Flores (2014), onde discuto o processo de tradução das Odes horacianas]. Um detalhe específico destas traduções é o uso absolutamente parco de pontuação, com o intuito mesmo de produzir certas ambiguidades de leitura, tal como a poesia romana antiga, que não tinha separação entre palavras, versos ou frases. Ao mesmo tempo, as traduções buscam um diálogo com a tradição das traduções anteriores de José Agostinho de Macedo (1806), Elpino Duriense (1807), Cabral de Mello (1853), Almeida Ferraz (2003) e Alexandre Hasegawa (2010), que infelizmente não poderei comentar aqui.
} 


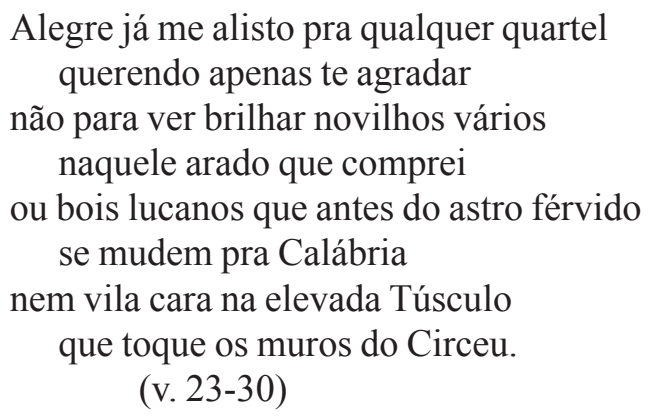

Mas poderíamos, como Johnson (2012, p. 77-100), ver nesta ênfase sobre a amizade uma preparação para os epodos 2, 3 e 4, de modo que o primeiro poema pouco a pouco passaria a ser visto como representação de uma figura hipócrita, que tenta disfarçar interesses escusos; então seria possível imaginar que a amizade de Horácio o força a seguir o patrono por interesse, assim como seu patrono é forçado a seguir César por interesse - ninguém estaria interessado na guerra de Otaviano e Marco Antônio/Cleópatra, mas as regras sociais os levariam ali, com um discurso velado de amizade; nesse sentido, já temos a possibilidade de um riso autoirônico presente desde a abertura do livro.

Na sequência da leitura, temos o segundo epodo:

Beatus ille qui procul negotiis, ut prisca gens mortalium, paterna rura bobus exercet suis solutus omnifaenore, neque excitatur classico miles truci neque horret iratum mare, forumque uitat et superba ciuium potentiorum limina.

É rico quem sem ter sequer negócios igual aos povos ancestrais trabalha todo o chão paterno com seus bois sem juros como seus grilhões que não se assusta com trombetas marciais nem teme o mar colérico que evita o fórum e a soberba dos umbrais dos grandes homens de poder. 
A construção irônica do segundo epodo cria dois ruídos no desenvolvimento linear da obra: em primeiro lugar, sugere continuar a fala que encerra o epodo inicial (convém sempre lembrar que a divisão entre poemas, no tempo de Horácio, não era clara, e que muitas vezes eram grafados num contínuo textual que borrava o limite entre poemas), o que nos levaria a crer que as palavras seriam do poeta Horácio, ainda no primeiro poema; em segundo lugar, o próprio epodo anula, ao final, o elogio da vida rústica, quando nos últimos quatro versos revela ser a fala do agiota Álfio, interessado em continuar suas práticas de extorsão e juros:

Haec ubi locutus faenerator Alfus,

iam iam futurus rusticus,

omnem redegit Idibus pecuniam,

quaerit Kalendis ponere.

Assim falando o agiota Álfio

já quase quase agricultor

recolhe todo seu dinheiro ao fim do mês

e empresta para o próximo.

(v. 67-70)

Nesse aspecto, o poema segue a técnica epigramática do aposdoketón (figura inesperada que ressignifica o que foi apresentado antes), porém liga os dois poemas do livro até o que o leitor possa fazer um corte entre eles. Essa possível confusão de vozes está no cerne das interpretações possíveis, já que instabilizam o tom da obra (WATSON, 2003, p. 75); e qualquer interpretação se torna ainda mais complexa, se levarmos em conta que o poema certamente dialoga com o clima geral das Bucólicas de Virgílio e que também responde ao final do segundo livro das suas contemporâneas Geórgicas, em que vemos também um louvor, dessa vez aparentemente inequívoco, da vida rural. ${ }^{5}$

${ }^{5}$ Cf. Mankin (1995, p. 63-64), sobre como a visão inequívoca de Virgílio pode ser simplista. Como Watson (2003, p. 76-77), não creio ser possível decidir se o poema de Horácio seria ou não anterior às Geórgicas; no entanto, poderíamos ver na sua contemporaneidade e no fato de que os dois poetas participavam do círculo de Mecenas, que os poetas deveriam ter conhecimento das obras, o que geraria uma espécie de diálogo pré-publicação em livro. Reconstituir as nuances desse diálogo seria de fato impossível, mas seria mais provável vermos na síntese horaciana um eco de Virgílio, do que um Virgílio ecoando Horácio de modo espalhado pelas Geórgicas. 
Seja como for, este poema também retoma uma prática arquiloquiana que vemos no frag. 19 West:

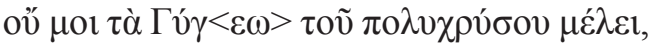

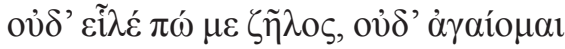

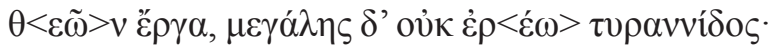

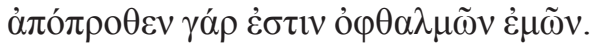
E não me importa Giges multiáureo e não me veio inveja nem cobiçarei os dons divinos nem poder tirânico - estão distantes muito além do meu olhar.

Embora no poema grego a voz pareça ser do poeta, sabemos por Aristóteles (Retórica 3.17) que ele seria dito por Caronte, um carpinteiro, e não pela persona do próprio Arquíloco.

Porém a construção horaciana é mais complexa que aquilo que pudemos ver no fragmento arquiloquiano: por um lado, o elogio ao campo parece ser sincero e é recorrente em toda a obra do poeta; ${ }^{6}$ por outro, a autoironia aqui se revela, porque é a voz do outro - o hipócrita que louva o campo, mas vive no epicentro da vida econômica da cidade - que interfere no poema próprio. Nesse caso, a pergunta seria se não poderíamos reler o poema com ênfase em seu exagero laudatório, uma vez que toda a crise do campo, nos anos 40 e 30 a.C., ${ }^{7}$ desaparece da tópica, e o labor constante (ao contrário do que lemos nas Geórgicas) não aparece em momento algum como contraponto realista aos prazeres do campo. Essa desmedida laudatória é já o indício da presença final de Álfio e deve ser fundida com a expectativa genérica de um iambo, que imediatamente destoaria do modelo laudatório, seu oposto. Assim, Horácio, que, como todos sabem, detinha uma uilla Sabina de porte no mínimo médio, doada por Mecenas, de certo modo se aproximaria inusitadamente da voz hipócrita de Álfio, num louvor exagerado do ideal rústico que ele próprio não estaria disposto a cumprir; com isso, teríamos uma continuidade da voz ambígua e autoirônica do poema 1 em suas

\footnotetext{
${ }^{6}$ Cf. Horácio, Sátiras 2.6, Odes 1.17, 1.31, 2.3, 2.11, 3.1, 3.29, 4.12 e Epistolas 1.7 e 1.16 , para ficarmos com poucos exemplos.

${ }^{7}$ Cf. Virgílio, Bucólicas 1, ou Tibulo 1.1 fazem referência ao confisco de pequenas propriedades.
} 
implicações de modelo de vida. Entretanto, essa aproximação não pode ser considerada simples fusão, e a instabilidade se torna ponto chave, porque, ao se aproximar de Álfio, Horácio também aproxima o leitor que compra os elogios inanes do campo, o que põe o descontentamento como tema central do poema (ROMANO, 1991, p. 948), tal como em Sátiras 1.1 ou 2.2. Assim, na passagem pelo segundo poema, o leitor também arrisca se ver num espelho complexo, caso reconheça no elogio vazio ao campo também sua parte descontente de indivíduo citadino.

A passagem do segundo para o terceiro epodo não parece gerar ambiguidades interpretativas: a mudança de tom é brusca, apesar da continuidade métrica:

\section{Parentis olim si quis impia manu \\ senile guttur fregerit, edit cicutis alium nocentius.}

Se alguém acaso ousar erguer a ímpia mão

e estrangular o velho pai

que coma um alho mais nocivo que cicuta!

(v. 1-3)

Neste poema de invectiva simpótica, vemos uma cena inesperada de brincadeira gastronômica: Mecenas colocou excesso de alho na comida de Horácio, que sente uma ardência por dentro e assim realiza um pequeno delírio imaginativo. A invectiva ridícula do banquete numa espécie de paródia de um $\sigma \chi \varepsilon \tau \lambda \imath 1 \alpha \sigma \mu$ ó (lamento indignado) pode então servir, como em parte dos iambos arcaicos, para reafirmar a amizade. ${ }^{8}$ Este poema realiza um caso raríssimo nas relações entre poeta e patrono; ele é, na verdade, único na poesia horaciana, e nos dá a ver um modelo de relação de amizade muito diverso do que apareceu no epodo 1. Como bem observa Watson (2003, p. 126), Horácio aqui deixa de lado a descrição fisiológica do que sente ao comer alho, para desdobrar as associações em termos legais, mitológicos e climáticos, que hiperbolizam o sofrimento intestinal (v. 5-18). Apesar de este poema

\footnotetext{
${ }^{8}$ Cf. Arquíloco (frags. 96, 117, 124), ou Catulo (6, 10, 12, etc.); embora em nenhum desses casos nós tenhamos exemplos míticos como em Horácio, ainda assim percebemos que o iambo, assim como a sátira, apresenta constantemente interesse por temas alimentares.
} 
ter sido considerado, com frequência, uma obra menor, ainda assim é possível vermos nele uma indicação das indisposições da guerra civil, capaz de anular amizades (MANKIN, 1995, p. 88), e, portanto, o jogo privado como ponto de risco dos convívios, se não houver um riso diverso daquele realizado na invectiva mais violenta: o ponto já estava em jogo no epodo 1, e a figura de Canídia pode sugerir isso ao longo de todo o livro, como veremos mais adiante. Mais importante é perceber como o encerramento do poema, muitas vezes visto como um fracasso do poeta iâmbico, é também a produção de um riso amigo:

At si quid umquam tale concupiueris, iocose Maecenas, precor manum puella sauio opponat tuo extrema et in sponda cubet.

Se você quer um tal horror eu vou rogar meu bom Mecenas fanfarrão que a tua menina expulse os beijos com a mão e durma alheia em teu colchão.

(v. 19-22)

Horácio, ao fazer uma imprecação fraca contra Mecenas (se este o atacar com alho novamente, ficará com bafo e perderá uma noite com sua amante), opera o contrarriso inter pares que equilibra as guerras civis e os hipócritas gananciosos que vimos anteriormente; mas isso só pode se dar porque o poeta aparece fragilizado e ridículo aos olhos de seus leitores. No ponto em que a verve invectiva do livro parece se anunciar, tudo se desfaz em autoironia: Horácio não é um Arquíloco, não é um Hipônax redivivo.

É então na tensão iniciada pelo falso ataque a Mecenas que chegamos ao quarto epodo: este poema realiza a primeira invectiva explícita e mais virulenta do livro, contra um arrivista, um ex-escravo que atingiu o posto de equestre (ponto mais alto do censo de bens em Roma) e o cargo de tribuno militar. Penso que, neste caso, valha a pena citar o poema por inteiro:

Lupis et agnis quanta sortito obtigit, tecum mihi discordia est, Hibericis peruste funibus latus et crura dura compede. 
Licet superbus ambules pecunia,

Fortuna non mutat genus.

Videsne, Sacram metiente te Viam

cum bis trium ulnarum toga,

ut ora uertat huc et huc euntium

liberrima indignatio?

"Sectus flagellis hic triumuiralibus

praeconis ad fastidium

arat Falerni mille fundi iugera

et Appiam mannis terit

sedilibusque magnus in primis eques

Othone contempto sedet!

Quid attinet tot ora nauium graui

rostrata duci pondere

contra latrones atque servilem manum

hoc, hoc tribuno militum?"

Tal como lobos e cordeiros não se dão sou só discórdia por você

que sente o lombo arder na corda ibérica

e as coxas duras nos grilhões.

Soberbo e rico pode se ostentar porém

fortuna não te dá raiz.

Já viu? você percorre a Via Sacra e traz

três metros dessa toga atroz

e assim se afasta quem passar aqui e ali

com rejeição libérrima?

Quem foi marcado por flagelos triunvirais

e gera náusea nos pregões

cultiva ao longo de Falerno alqueires mil

cavalga pôneis na Ápia

e como rico equestre no primeiro rol

despreza toda a lei de Otão!

De que valeu guiar as mais pesadas naus

de proas entre os esporões

contra os ladrões e contra as hordas serviçais

se ele é tribuno militar? 
Em primeiro lugar, é fundamental lembrar que o poema já foi diversas vezes comparado a Anacreonte frag. 388 Campbell:

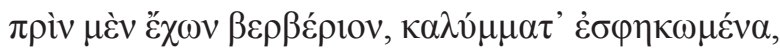

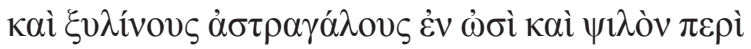

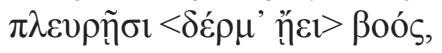

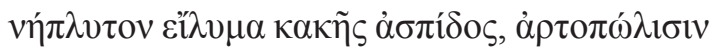

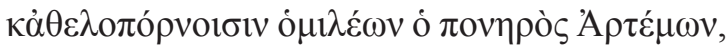

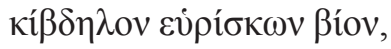

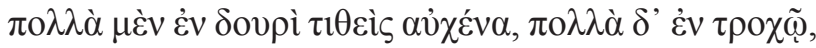

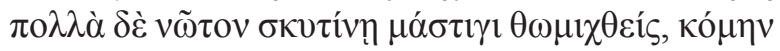

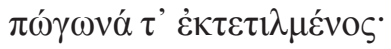

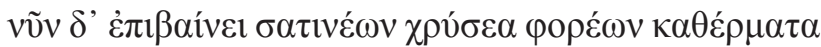

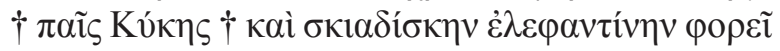

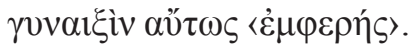

Sempre vestiu trapos com seu gorro de tom decrépito dados de pau tinha na orelha e entre seu ventre usava só aquele couro cru de boi

que ele jamais pôs pra lavar - capa do escudo péssimo: putas michês e outros então só vadiavam com Ártemon a revelar a vida vil

sempre o pescoço ia pousar junto de roda e tronco atroz sempre sentiu lombos a arder pelo poder do látego cabelo e barba sem raiz.

Hoje dispõe carros e traz ouro sutil junto do brinco o tal filho de Cice e ergue nas mãos uma sombrinha só-marfim igual mulher com guarda-sol. ${ }^{9}$

No caso do poema horaciano, ao menos desde Porfirião, esse liberto anônimo é identificado como Pompeio Menas, ou Menodoro,

\footnotetext{
${ }^{9} \mathrm{Tal}$ como as traduções dos Epodos que apresento, também esta busca emular o ritmo do original a partir de uma organização rítmica do seguinte modo: $2 \mathrm{x}-\mathrm{u} u--\mathrm{u} u--\mathrm{u}$ $\mathrm{u}-\mathrm{u}-\mathrm{u}-;$ e $1 \mathrm{x} \mathrm{u}-\mathrm{u}-\mathrm{u}-\mathrm{u}-)$.
} 
antigo escravo de Pompeu Magno que de fato chegou a equestre, foi general naval de Sexto Pompeio e por fim voltou-se para o grupo de Otaviano em tempo de vencer a batalha de Náuloco, o que lhe garantiu uma boa posição na política subsequente até a morte, certamente antes da batalha do Ácio. No entanto, não sabemos se Menas chegou a ocupar o cargo de tribuno militar, de modo que hoje comentadores não se sentem obrigados a procurar um indivíduo específico por trás dessa figura para lerem o poema como um ataque a um personagem típico em Roma. ${ }^{10}$ De qualquer forma, mais importante do que determinar de quem seria o liberto em questão é notarmos que, assim como o liberto, também o $e u$ do poema não se revela plenamente, de modo que o mais comum porém, não obrigatório - é o identificarmos com o próprio Horácio. Nesse caso, apesar de o tema do arrivista ser típico em vários gêneros, ${ }^{11}$ há aqui uma ironia biográfica em jogo que parece inovar a tópica: sabemos que o próprio Horácio sofreu por ser filho de um liberto, ${ }^{12}$ que ele próprio teve oportunidade de se sentar nas cadeiras dos equestres e que também já havia ocupado precisamente o cargo de tribuno militar de Bruto na batalha de Filipos; portanto, ao atacar um liberto agora, o poeta encena a crítica a seu próprio pai e a si mesmo; assim ele revela um jogo de ódios internos da sociedade romana, comumente fechada sobre certos códigos de aristocracia familiar. Como nos poemas anteriores, o ponto crucial está no fato de que o poeta faz sua zombaria ao outro exatamente num ponto em que ele próprio se revela frágil ou suspeito de hipocrisia, o riso do outro e a sua derrisão sendo atravessados pelo riso de si mesmo e a sua autoderrisão. Aqui teríamos talvez uma estilização arquiloquiana em que a persona do poema se revela mais repreensível do que a vítima de seu ataque. Se levarmos ao limite a ideia de uma persona repreensível, tornase mais importante observar que não sabemos nada de quem fala, nem mesmo o gênero: é possível que seja um homem ou mesmo uma mulher que irrompe no livro, tal como Álfio, e que sua vítima seria então o próprio Horácio! Mas a tensão não se resolve entre a voz ser do poeta autoirônico ou de uma persona fictícia que o ataca tal como Mecenas, e essa tensão

\footnotetext{
${ }^{10}$ Outra hipótese menos considerada seria um certo Védio Rufo, talvez a figura descrita por Cícero (A Ático 5.1.35).

${ }^{11}$ Comédia velha, Comédia Nova, sátira, epigrama, etc. (WATSON, 2003, p. 146).

${ }^{12}$ Cf. libertino patre natus, expressão que assola a sátira 1.6, e o estudo de Williams (1995).
} 
entre o eu e o outro parece ser constitutiva dos problemas políticos que aí aparecem. Enfim, na realização da invectiva iâmbica plena, estamos desconcertados sobre o objeto e a persona, sendo que Horácio pode ocupar os dois postos, e pode mesmo retornar às possibilidades hipócritas anunciadas pelos dois primeiros epodos; no entanto, aqui, como na fala de Álfio, se aceitamos a fala da persona, de algum modo cedemos à guerra civil pela disputa de espaços políticos e compramos fácil a marca do conservadorismo. Horácio, quando instabiliza mais uma vez a interpretação do poema, lança a pergunta de volta: que lugar o leitor ocupa no poema? Aqui chegamos ao quinto epodo:

At o deorum quidquid in caelo regit

terras et humanum genus,

quid iste fert tumultus? Aut quid omnium

uultus in unum me truces?

Per liberos te, si uocata partubus

Lucina ueris affuit,

per hoc inane purpurae decus precor,

per inprobaturum haec Iouem,

quid ut nouerca me intueris aut uti

petita ferro belua?

Mas pelos deuses todos deste vasto céu

que regem homens sobre o chão

o que entender de tal discórdia e desse olhar

que todos lançam contra mim?

Por tua prole se é que um dia já chamou

Lucina para partejar

por esta inútil vestimenta púrpura

por Jove avesso a tal horror

por que você me encara igual madrasta atroz

ou feito fera ao se ferir?

$$
\text { (v. 1-10) }
$$

De quem é essa fala inicial? Nos primeiros versos, poderíamos pensar que ainda estamos no epodo 4 e que o ataque ao arrivista leva o poeta a uma apóstrofe aos deuses; mas a sequência dos versos logo revela que temos um novo interlocutor, que mais adiante descobriremos ser um menino (também anônimo como o liberto) que tenta agora 
dissuadir Canídia de realizar um feitiço. A interpretação da peça passa, em grande parte, pela discussão sobre sua seriedade ou não: estamos diante de um poema que provocaria horror ou riso? Os romanos o leriam como jogo literário, ou como descrição de bruxarias reais? A resposta é impossível, mas podemos ver que haveria, em todo caso, uma tensão entre as respostas: este epodo sobre magia negra e filtros amorosos imediatamente remonta ao idílio 2 de Teócrito e à bucólica 8 de Virgílio (clara imitação do anterior); no entanto, mais do que uma fascinação literária, o imaginário sobre magia de fato marcava práticas culturais gregas e romanas, que são verificáveis nos Papiros mágicos; para além disso, sabemos, por exemplo, que nas Doze tábuas havia certa regulação à magia; que em 97 a.C. o senado romano fez um decreto contra magos que proibia o sacrifício humano (cf. Plínio, História natural, 30.12); e que em 81 a.C. foi promulgada a Lex Cornelia de sicariis et ueneficiis, que atacava a magia negra (Justiniano, Instituições 4.18.5). Além disso, acusações de magia negra parecem ter sido parte da política de ataque cesariano aos seus inimigos do lado de Pompeu (cf. Plínio, História natural 7 e Lucano, Farsália, 6); de modo que Augusto também parece ter usado o tema como censura a Marco Antônio, alegando que este seria enfeitiçado por Cleópatra (Plutarco, Antônio, 37.4 e 60.1). Diante disso, é possível apurar que havia, se não uma prática recorrente de sacrifício humano em rituais e filtros amorosos, ao menos um imaginário poderoso que levava os romanos a utilizarem o tema como fundamento para ataque político e para legislação. ${ }^{13}$ Por outro lado, quanto a sua organização dialogada e encenada, apesar de termos exemplares em Arquíloco e Hipônax, o poema já foi diversas vezes comparado ao mimo antigo, como as obras de Herodas, de modo que Elisa Romano o chama "mimiambo" (ROMANO, 1991, p. 960); do mesmo modo, seria possível ver Canídia como uma archimima, que representa e rege o grupo de mimae, numa apresentação. Esse vínculo genérico reforçaria uma leitura menos séria da peça, além de dar um caráter mais cômico ao conjunto sinistro.

O que temos, em resumo, é que Canídia, associada a mais três bruxas (Sagana, Veia e Fólia), prepara um ritual para enterrar o menino (o verso 7 indica que se trata de um cidadão romano) até o pescoço e deixá-lo morrer de fome, para depois usar sua medula e o fígado como

\footnotetext{
${ }^{13}$ Watson (2003, p. 174-191) faz uma longa discussão sobre o assunto, com inúmeras referências cruzadas.
} 
material para o preparo de uma poção amorosa, a fim de resgatar o amor de Varo, um velho sedutor que no momento vai ao bairro de Subura (famoso red district romano) atrás de amantes. Como veremos, Canídia antes tenta um feitiço que fracassa (v. 61-72), para depois se voltar ao assassinato do jovem; este, ao perceber que nada mais o pode salvar, muda o modelo do discurso que inicia o poema e assim se apresenta:

Sub haec puer iam non, ut ante, mollibus

lenire uerbis impias,

sed dubius unde rumperet silentium, misit Thyesteas preces:

"Venena miscent fas nefasque, non ualent conuertere humanam uicem.

Diris agam uos; dira detestatio nulla expiatur nictima.

Quin, ubi perire iussus exspirauero, nocturnus occurram Furor petamque uultus umbra curuis unguibus, quae uis deorum est Manium, et inquietis adsidens praecordiis

pauore somnos auferam.

Vos turba uicatim hinc et hinc saxis petens contundet obscenas anus, post insepulta membra different lupi et Esquilinae alites, neque hoc parentes, heu, mihi superstites, effugerit spectaculum".

Com isso o jovem já não tenta amolecer na fala às velhas ímpias e sem saber romper o seu silêncio igual Tiestes conjurou.

Feitiços podem confundir o bem e o mal mas não o troco dos mortais.

Eu lanço maldições e meu maldito horror não finda em sacrifícios.

Assim que em morte condenada eu perecer serei noturna Fúria com garra curva atacarei na tez vocês qual fosse o Mane mais fatal 
depois pousando em seus insanos corações

darei ao sono meu terror

em cada canto o povo deve apedrejar

às velhas vis sacrílegas

e no Esquilino as insepultas servirão

de pasto a lobo e pássaro

assim meus pais que vão sobreviver a mim

verão seu espetáculo.

(v. 83-102)

Algo terrível se opera nessa mudança: de um jovem impúbere (v. 13), ele se transforma primeiro na figura trágica de Tiestes após comer a carne dos filhos e fazer maldições (tópica que depois será desenvolvida pelo Tiestes de Sêneca), para então se tornar ele próprio uma Fúria que vingará a própria morte. Ao mesmo tempo profeta e amaldiçoador, o menino anônimo revela o fim próximo das bruxas, por apedrejamento seguido de exposição do corpo a pássaros e lobos. E mais: tudo servirá como espetáculo para os pais do jovem, assim como este poema e o ritual servem de espetáculo para o leitor. Aqui chegamos, talvez, ao problema central da interpretação do epodo: por um lado, a voz horaciana parece concordar plenamente com a fragilidade do menino, com sua postura romana e com sua crítica à barbárie das matronas feiticeiras; a voz de Horácio, de fato, foi uma série de fracassos autoirônicos até o momento (possível hipocrisia no epodo 1, descontentamento hipócrita no epodo 2, falso ataque no epodo 3, autodestruição no epodo 4), assim como o menino parece caminhar para o fracasso. Por outro lado, a nova figuração do menino extrapola tudo que a poética horaciana nos anunciou até aqui: ele se revela uma figuração da vingança por forças do além, enquanto Horácio mal consegue se vingar de alho na comida. De modo similar, Canídia estabelece um relação ambígua: por um lado, é a bruxa bárbara que simboliza talvez a guerra civil em Roma, ou a degradação dos costumes tradicionais; por outro, também ela é uma especialista no fracasso de seus ataques, tanto no primeiro feitiço (v. 61-72) como no segundo. E aqui é preciso analisarmos a abertura ao fim do poema, porque, quando chegamos ao fim da maldição infantil, o epodo se encerra sem nos dizer o que foi o resultado; então podemos nos perguntar se o menino morre ou não. Decerto, não há resposta unívoca, mas podemos ao menos imaginar alguns problemas: na sátira 1.8, vemos como a 
estátua de madeira de um Priapo dá fim ao feitiço de Canídia graças a uma flatulência; trata-se de uma quebra do silentium ritual, que ao mesmo tempo provoca riso no leitor e horror nas bruxas, de modo que elas se dispersam. Aqui, de modo similar, porém mais macabro, o menino também rompe o silentium do ritual com sua maldição; nesse sentido, ele ameaça aniquilar o efeito ritual que demanda o silêncio como condição de sua realização. A maldição (dirae) é então também um contrafeitiço que põe Canídia num segundo fracasso potencial, ou seja, quando a voz do menino irrompe violentamente, sua fala é simultaneamente a defesa do indefeso e o ataque daquela que reiteradamente fracassa; essa duplicidade da fala é a duplicidade horaciana que temos visto até aqui, porque se dá numa confusão entre um pedido de apoio de seu leitor e um risco de o amedrontar, tornando-se o menino então pior do que as bruxas. Poderíamos nos perguntar então: diante da figura da guerra civil e da barbárie internalizada (Canídia), haveria uma resposta possível para além de um ataque ainda mais virulento (menino)? É nesta hesitação que podemos ler o epodo 6 em sua força programática:

Quid inmerentis hospites uexas canis, ignauus aduersum lupos?

Quin huc inanis, si potes, uertis minas et me remorsurum petis?

Nam qualis aut Molossus aut fuluos Lacon,

amica uis pastoribus, agam per altas aure sublata niuis, quaecumque praecedet fera;

tu, cum timenda uoce complesti nemus, proiectum odoraris cibum.

Caue caue, namque in malos asperrimus parata tollo cornua, qualis Lycambae spretus infido gener aut acer hostis Bupalo.

An si quis atro dente me petiverit, inultus ut flebo puer?

Por que você ataca os inocentes cão que contra lobos nunca vai?

Então que tal me ameaçar em vão e assim sentir que volto pra morder? 
Igual molosso igual um cão lacônio

que é força amiga dum pastor

eu vou por altas neves com orelha em pé

atrás da fera que passou

você porém já enche a mata de temor

mas cheira e come só ração.

Cuidado! Contra todos que me fazem mal

preparo o chifre mais hostil

que nem o genro de Licambes desleal

e o detrator de Búpalo.

Será que quando um dente preto me morder

eu choro inulto igual rapaz?

Como tentei demonstrar até aqui, a ironia horaciana nos fez enfrentar várias vezes a pergunta "o que ele quer dizer com isso?", sem conseguirmos uma resposta unívoca; pelo contrário, os primeiros cinco epodos mostraram uma pluralidade desconcertante de vozes e de possíveis relações entre elas e o mundo político romano. Quando chegamos ao epodo 6, tudo indica que perdemos a "voz" horaciana em sua univocidade, e é nesse momento que tudo parece indicar que estamos diante de um anúncio programático, mesmo que este poema já tenha sido criticado por sua construção sem foco (WATSON, 2003, p. 253-254). Depois de se dirigir ao seu inimigo como a um cão que ladra aos inocentes, mas receia enfrentar lobos (v. 1-2), o poeta propõe que ele venha contra si, e ameaça morder de volta (v. 3-4, remorsurum), o que faz com que ele próprio também se torne um cachorro feroz. Isso o leva a uma comparação entre dois tipos de cães pastoris: enquanto o poeta se apresenta como um fiel perseguidor, o inimigo apenas amedronta, mas busca comer a comida oferecida pelo dono (v. 5-10). Assim, metamorfoseado inesperadamente em touro, ${ }^{14}$ o poeta ameaça atacar (v. 11-12). Nos versos 13-14, ponto fulcral do poema, Horácio se compara a duas figuras fundamentais da poesia iâmbica grega: em primeiro lugar, Arquíloco de Paros teria sido genro de um certo Licambes, que teria

\footnotetext{
${ }^{14}$ Embora a metamorfose abrupta incomode muitos comentadores, a imagem do poeta invectivo como um touro já havia aparecido em Sátiras 1.4.34. Mais que isso, temos aqui na verdade uma dupla transformação, já que o poeta passa de cão a poeta iâmbico grego, como Arquíloco e Hipônax, esse movimento fazendo então um crescendo animal para chegar ao gênero literário.
} 
prometido uma de suas filhas, Neobule, em casamento; no entanto, Licambes rompeu sua promessa; por isso, Arquíloco atacou o ex-sogro e a ex-noiva e a ex-cunhada de tal modo, que eles cometeram suicídio pela vergonha e o desespero causados pela poesia iâmbica. Em segundo lugar, Hipônax de Éfeso teria atacado o escultor Búpalo, depois que este fez uma imagem caricatural do poeta; novamente, o resultado foi o suicídio. ${ }^{15}$ Curiosamente, aqui vemos apenas os nomes das vítimas, e não os dos poetas, ao passo que na construção do próprio poema é o nome do adversário que não aparece, o que poderia ser lido como uma espécie de fracasso, ou de impotência horaciana. Mas, como se não bastasse, os últimos dois versos fazem uma comparação dissímile entre o poeta e um rapaz inulto, imagem que inequivocamente nos remete ao epodo anterior. O que fazer então com a sequência? Vejamos primeiro algumas possibilidades de leitura. Parte dos manuscritos dá um título a esta peça a partir do nome da possível vítima do poeta, que poderia ser um dos três escritores: Mévio (cf. o poema 10), Bibáculo (que já havia sido zombado em Sátiras 2.5), ou Cássio Severo (caso improvável, já que devia ser ainda criança no período da escrita do poema). No entanto, nada no poema aponta para a necessidade de que o cão seja um escritor; mais importante que isso parece ser uma poética iâmbica da defesa, em contraponto ao ataque gratuito, ou ao ataque covarde; nesse caso, a poesia deste livro serviria como autodefesa verbal (o que o vincularia à história de Arquíloco contra Licambes e à de Hipônax contra Búpalo), que então também serve como defesa pra um público maior de inocentes que vêm sendo atacados, ${ }^{16}$ uma tópica similar ao que vemos em Sátiras 1.4. É importante observar que, embora este poema lembre a sátira romana de Lucílio (frags. 87-93), a tópica da animalidade é muito cara ao iambo grego arcaico (Arquíloco, frags. 23, 201, 223) e helenístico (Calímaco frag. 380 Pfeiffer).

Ora, o que se anuncia neste Horácio que promete atacar? Precisamente, uma promessa. Se os primeiros epodos, por sua constituição ambígua, realizam parcial ou equivocamente um projeto de poesia arquiloquiana ou hiponactiana, este epodo programático nos

\footnotetext{
${ }^{15}$ Os testemunhos antigos sobre essas histórias podem ser consultados em West (1989). ${ }^{16}$ Como bem observara Eduard Fraenkel (1957, p. 57), Horácio deixa bem claro que ele próprio não foi atacado pelo cão e que isso poderia sugerir que estamos diante de um poema sem adversário real (WATSON 2003, p. 254).
} 
mostra uma nova possibilidade de voz para um mundo conturbado pela guerra civil. Em 30 a.C., provável ano de publicação dos Epodos, um romano não via as guerras civis como já terminadas, mas via na Batalha do Ácio um aceno para a paz; os Epodos são uma espécie de resposta muito complexa a esse clima de esperança receosa e podem então ser lidos como uma poética irônica que anuncia uma possibilidade de política do convívio. No lugar da afirmação de um eu coerente e virtuoso, o que temos é constantemente uma persona poética que a cada instante se autoironiza para poder censurar pontos sociais diversos: a hipocrisia bélica (1), o descontentamento constante seguido de manutenção do status quo de predação monetária do outro (2), os ataques lúdicos entre amigos como risco da guerra civil e sua possível diluição no riso (3), o ataque ao outro que é mais propriamente um eu (4) e a guerra civil em microescala de bruxaria e vingança (5), para então vermos a invectiva como promessa de autodefesa de si e dos outros (6), uma promessa que só se cumpre quando se alia a uma tradição destrutiva de Arquíloco e Hipônax, mas que, paradoxalmente, deixa de cumprir a parte mais violenta do ataque: o nome da vítima. A todo instante, a voz que ataca torna-se potencialmente a voz atacada, e a ironia se mostra como uma arma incessante que mobiliza pontos de vista contraditórios; porém, muito diferente do que vemos em Foster Wallace, aqui a ironia pode ter uma potencialidade política muito específica, embora de fato não possa se resumir a um querer dizer unívoco. De qualquer modo, uma poética iâmbica da promessa invectiva, sobretudo vinda de uma voz perfurada de fracassos e desvios, torna-se potencialmente uma política de convívio da pluralidade de vozes. Num mundo rasgado pela guerra civil, num espaço que então começava a se redesenhar pela chance da paz, o iambo como promessa de ataque, um ataque que, se vier a acontecer, será frágil, inconsistente em suas bases, permite uma reutilização do riso como desarmamento; nesse aspecto, Horácio precisa ser e não ser o menino do epodo 5: por um lado, sua voz ataca apenas diante do risco iminente (ele não chorará como um rapaz inulto); por outro, o risco da violência desmedida não cabe no epodo horaciano; em vez disso, as vozes deslizam, iludem, prometem ataques que não se cumprem inteiramente. Restaria então lermos o resto do livro dos Epodos para vermos como também essa promessa se frustra em partes. Diante das inconsistências entre o programa aqui apresentado e as constantes falhas do poeta ao longo do livro, Lindsay Watson afirmou que o poema deveria ser lido como pseudo-programático (WATSON, 
2003, p. 256). Apesar de concordar com a afirmação de Watson, que entende a programática como instável e contraditória, aqui tentei levar o problema além, para incorporar as inconsistências a um projeto de poética e política, que fizessem do constante fracasso do poeta uma imagem da política possível, um iambo da autodefesa, que em parte evita a virulência dos nomes e prefere fazer de seu fracasso um lugar de diálogo e pluralidade de vozes. Horácio, também nisso, fracassará: o poeta que sonha uma política da ironia a sonha porque é frágil e pode cair, a sua linha é delicada e ela nos convoca ao desafio.

\section{Referências}

ALMEIDA FERRAZ, B. P. Horácio: Odes e Epodos. Trad. e notas Bento Prado de Almeida Ferraz; introdução de Antonio Medina Rodrigues; organização de Anna Lia Amaral de Almeida Prado. São Paulo: Martins Fontes, 2003.

CABRAL DE MELLO, J. A. Odes de Q. Horacio Flacco traduzidas em verso na lingua portugueza, por José Augusto Cabral de Mello. Angra do Heroismo: Typ. do Angrense, do Visconde de Bruges, 1853.

CARRUBBA, R. W. The Epodes of Horace: a study in poetic arrangement. Paris: Mouton, 1969.

DURIENSE, E. (Antonio Ribeiro dos Santos). A lyrica de Q. Horacio Flacco, poeta romano, trasladada literalmente em verso portuguez por Elpino Duriense: tomo II. Lisboa: Imprensa Regia, 1807.

FRAENKEL, E. Horace. Oxford: Oxford University Press, 1957.

FLORES, G. G. Uma poesia de mosaico nas "Odes" de Horácio: comentário e tradução poética. 2014. 413 f. Tese (Doutorado em Letras Clássicas, Área de Letras Clássicas) - Faculdade de Filosofia, Letras e Ciências Humanas da Universidade de São Paulo, 2014.

HASEGAWA, A. Dispositio e distinção de gêneros nos "Epodos" de Horácio: estudo acompanhado de tradução em verso. 2010. 227 f. Tese (Doutorado em Letras Clássicas, Área de Letras Clássicas) - Faculdade de Filosofia, Letras e Ciências Humanas da Universidade de São Paulo, 2010. 
HORÁCIO. Obras Completas. Trad. de Elpino Duriense, José Agostinho de Macedo, Antônio Luiz Seabra e Francisco Antônio Picot. São Paulo: Edições Cultura, 1941.

JOHNSON, T. S. Horace's iambic criticism: casting blame ("iambike poiesis"). Leiden/Boston: Brill, 2012.

MACEDO, José Agostinho. Obras de Horacio traduzidas em verso portuguez por José Agostinho de Macedo: tomo I - Os quatro livros das "Odes", e "Epodos". Lisboa: Imprensa Regia, 1806.

MANKIN, D. Horace: "Epodes". Cambridge: Cambridge University Press, 1995.

ROMANO, E. Q. Orazio Flacco: Le opere I - Le "Odi”, il "Carme Secolare", gli "Epodi". Tomo secondo, commento di Elisa Romano. Roma: Libreria dello Stato, 1991.

SHACKLETON BAILEY, D. R. Horatius, opera. $4^{\text {th }}$. ed. Teubner: De Gruyter, 2001.

VILLENEUVE, F. Horace: tome 1 - “Odes" et "Épodes". Paris: Les Belles Lettres, 1946.

WATSON, L. C. A commentary on Horace's Epodes. Oxford: Oxford University Press, 2003.

WALLACE, D. F. I de ironia. Revista Serrote. Rio de Janeiro, n. 6, p. 184-187, 2009.

WEST, M. Iambi et elegi Graeci ante Alexandrum cantati. Oxford: Oxford University Press, 1989 (2 v.).

WILLIAMS, G. Libertino patre natus: true or false? In: HARRISON, S. J. (Org.). Homage to Horace: a bimillenary celebration. Oxford: Oxford University Press, 1995. p. 296-313. 